\title{
A CONSTRUÇÃO DA IMAGEM POLÍTICA DE DILMA ROUSSEFF COMO MÃE DO POVO BRASILEIRO ${ }^{1}$
}

Teresinha Maria de Carvalho Cruz Pires

\begin{abstract}
Resumo
Propõe-se demonstrar como a campanha eleitoral de Dilma Rousseff (PT) foi direcionada para apresentá-la como candidata do Lulismo e como tal ancorou-se em uma complexa estratégia de construção da imagem política da candidata como Mãe do povo brasileiro. Com vistas a esse propósito, foi realizada uma análise qualitativa do discurso político tendo como corpus de análise: discursos proferidos em eventos públicos, em 2008 e 2009, pelo então presidente da República, Lula; o filme Lula, o filho do Brasil, lançado em janeiro de 2010; e 20 programas televisivos que compuseram o Horário Gratuito Político Eleitoral (HGPE) da candidata, veiculados entre os dias 17 de agosto e 30 de setembro de 2010. Mostra-se que o uso dessa metáfora tanto possibilitou a sustentação do argumento de que o modelo de governo de Dilma era o mesmo do presidente da República, Luiz Inácio Lula da Silva, quanto funcionou como apelo emocional para despertar a atenção dos eleitores e motivar o processamento da informação política.
\end{abstract}

Palavras-chave: Lulismo; Campanha Eleitoral; Imagem Pública Política; Discurso Político; Estratégias Sensíveis.

\begin{abstract}
It is intended to show how the electoral campaign of Dilma Rousseff (PT) was conducted to present her as the candidate of the Lulism and in this way it was anchored in a complex candidate political image construction strategy as Mother of the Brazilian people. To achieve this purpose, a qualitative analysis of the political speech was carried through having as analysis corpus: speeches pronounced in public events, in 2008 and 2009, by the Brazilian president, at that moment, Lula; the film Lula, the son of Brazil, launched in January 2010; and 20 television programs that composed the free time for political propaganda (Horário Gratuito Político Eleitoral - HGPE) of the candidate, exhibited from August 17th to September 30th, 2010. It is revealed that the use of such metaphor made possible the sustentation of the argument that Dilma's model of government was the same of the Brazilian president, Luiz Inácio Lula da Silva, as much as it functioned as an emotional appeal to draw the voters' attention and to motivate the processing of the political information.
\end{abstract}

Keywords: Lulism; Electoral Campaign; Political Public Image; Political Speech; Sensible Strategies.

1 Esta é uma versão revisada do artigo apresentado no IV Congresso Latino-Americano de Opinião Pública da WAPOR, realizado em Belo Horizonte, no período de 4 a 6 de maio de 2011.

REVISTA DEBATES, Porto Alegre, v.5, n.1, p. 139-162, jan.-jun. 2011. 
"No Brasil [...] 52\% da população somos mulheres e os $48 \%$ restantes são nossos filhos" (Dilma, El País, 20 de junho de 2010).

\section{Introdução}

Fevereiro de 2009. A então ministra da Casa Civil, Dilma Rousseff (PT), anuncia, em grande estilo, no Encontro Nacional com Novos Prefeitos e Prefeitas, o projeto Minha Casa Minha Vida, que previa a construção de 1 milhão de casas populares subsidiadas em parte pelo governo federal. Os partidos de oposição PSDB (Partido da Social Democracia Brasileira) e DEM (Democratas), por considerarem tal anúncio início de campanha eleitoral, entraram com representação na Justiça Eleitoral. Houve antecipação na agenda política e na cobertura da mídia. Nesta última, especificamente, chama a atenção como as opiniões publicadas de jornalistas políticos, especialistas em marketing político e em pesquisas de opinião pública, passam a ser articuladas em torno da questão: a ministra-chefe da Casa Civil, Dilma Rousseff, será candidata do Lulismo ou do Petismo²?

A proposta é demonstrar como a campanha eleitoral de Dilma foi direcionada para apresentá-la como candidata do Lulismo. Postula-se, ainda, que tal apresentação ancorou-se em uma complexa - e bem-sucedida estratégia de construção da imagem pública política da candidata como Mãe do povo brasileiro. Advoga-se que o uso estratégico dessa alegoria feminina possibilitou tanto a sustentação do argumento de que o modelo de governo de Dilma Rousseff era o mesmo do presidente da República, Luiz Inácio Lula da Silva, como funcionou como apelo emocional cumprindo bem o papel primordial de "direcionar a atenção e motivar o processamento da informação" (LAVAREDA, 2009, p. 197); objetivos últimos de uma propaganda eleitoral. Acredita-se que tal análise possa contribuir tanto com estudos que se propõem a examinar a estratégia de comunicação de campanhas políticas de candidatura feminina em eleição majoritária quanto com aqueles que privilegiam o entendimento de tal estratégia sob o prisma da relação entre afeto e política.

Assim, com vistas a esse propósito de análise qualitativa do discurso político de apresentação de Dilma Rousseff como mãe do povo brasileiro, o corpus de análise foi constituído intencionalmente. De modo a documentar a presença de tal discurso antes do dia 13 de junho de 2010 - data de lançamento oficial da candidatura de Dilma - recorreu-se a discursos

\footnotetext{
2 Sobre a imagem política de Dilma que estava sendo construída, em 2009, por editorialistas e colunistas do jornal Folha de S. Paulo ver o artigo de Castro e Pires (2009). Nele ressalta-se: "[...] a imagem pública da candidatura de Dilma Rousseff, que os articulistas da 'Folha de S. Paulo' estão tentando construir, contém os elementos atribuídos ao lulismo - sem os traços do 'carisma popular', oriundo da extração de classe de Lula - mais do que aqueles que poderiam ser identificados com o petismo, sendo que o elemento mais forte será 'o risco do continuísmo de tudo o que o lulismo representa', como sugere Fernando Henrique Cardoso (2009) em seu texto intitulado Para onde vamos?" (CASTRO e PIRES, 2009, p. 20, grifos nossos).
} 
proferidos em eventos públicos, em 2008 e 2009, pelo então presidente da República, Lula, publicados por Kamel (2009); à entrevista concedida pelo marqueteiro João Santana - responsável pelas propagandas de TV e rádio de Dilma - ao jornalista da Folha de S. Paulo, Fernando Rodrigues (2010); e à realização de uma análise fílmica de Lula, o filho do Brasil, produzido por Luiz Carlos Barreto, lançado em janeiro de 2010. Já para o estudo de seu uso ao longo da campanha, o material empírico foi composto pelos 20 programas televisivos que compuseram o Horário Gratuito Político Eleitoral (HGPE), veiculados entre os dias 17 de agosto e 30 de setembro de 2010, portanto, anteriores à eleição em primeiro turno; e por 45 comerciais que também foram veiculados nesse período.

Cabe informar que já foi realizado um mapeamento inicial de todos esses programas e comerciais, atentando-se para o roteiro, as imagens, as cores, a música, a locução ou narração e o processo de edição, conforme sugere Lavareda (2009). Além desses, buscou-se considerar o conjunto dos programas como uma única narrativa de modo a perceber recorrências tanto em termos das estratégias de enunciação quanto nos planos dos enunciados; os atores em cena e, em especial, os momentos nos quais Lula se fez presente, além da candidata. Neste artigo, apresenta-se, em primeira versão, o resultado da observação, análise e interpretação desse rico e extenso material.

\section{Mãe do povo brasileiro: modelo quimérico de bom governo}

Mãe do povo brasileiro foi, na verdade, uma adaptação. O qualificativo mãe foi, publicamente, atribuído por Lula a Dilma em 2008. No dia 7 de março de 2008, por ocasião da assinatura de ordem de início de obras do Programa de Aceleração do Crescimento (PAC) na comunidade do Complexo do Alemão, na cidade do Rio de Janeiro, Dilma Rousseff recebe de Lula o epíteto de mãe do PAC: "A Dilma é uma espécie de mãe do PAC; é ela que cuida, é ela que acompanha, é ela que vai cobrar junto com o Márcio Fontes [ministro das Cidades] se as obras estão andando ou não estão andando" (LULA apud KAMEL, 2009, p. 247, grifos nossos).

Em abril do mesmo ano, Lula, em dois eventos que participou em Minas Gerais, retoma e esclarece melhor tal qualificativo atribuído a sua ministra:

[...] Outro dia, no Rio de Janeiro, eu disse que a Dilma era a mãe do PAC. E por que ela é a mãe do PAC? É porque o PAC só funciona porque esta mulher, certamente, toma mais conta do PAC do que tomou conta da filha dela. E por que eu digo isso? Porque todo mundo aqui que é pai sabe. Quando tem uma filha ou um filho que está com 14, 15 anos, eles não querem mais saber do pai. Nós somos coroas, nós estamos superados, as músicas não combinam, a roupa não combina, os amigos não combinam; eles querem liberdade. Então, a 
filha da Dilma certamente foi assim. Mas o PAC não quer liberdade, o PAC quer controle, fiscalização, acompanhamento. Porque, senão ele não funciona (17/4/08, Belo Horizonte - MG. Visita às obras do projeto de urbanização da Vila São José).

Eu disse agora há pouco, em Belo Horizonte: a Dilma é, na verdade, a mãe, a avó e a tia do PAC. Porque eu aprendi que se a gente anuncia uma obra e não fica atrás dela o tempo inteiro, essa obra não acontece (17/4/08, Ribeirão das Neves - MG. Assinatura de ordens de serviço de obras do PAC em municípios do Estado de Minas Gerais) (LULA apud KAMEL, 2009, p. 247).

Interessante destacar que nessa ocasião parece que não havia por parte de Lula a intenção de dotar Mãe do PAC de sentido eleitoral; pelo contrário, na semana seguinte a tais pronunciamentos, em entrevista exclusiva aos Diários Associados, ele chega a dizer que só a capacidade de gerenciamento de Dilma não a habilitava a ser candidata à presidência:

A Dilma é de uma capacidade de gerenciamento impecável. E, sobretudo, é aquilo que a gente gosta, caxias. É uma pessoa a quem você dá um compromisso, ela cobra 24 horas por dia, ela não dorme. Se você quiser um trabalho, ela vara a noite trabalhando para te entregar o produto. Então, eu acho uma figura extraordinária. Agora, entre ser uma figura extraordinária para gerenciar e ser candidata a presidente é uma outra conversa, porque aí tem um ingrediente chamado política, que exige outras credenciais (24/4/08, Brasília - DF. Entrevista exclusiva aos Diários Associados) (LULA apud KAMEL, 2009, p. 248, grifos nossos).

Entretanto, em fevereiro de 2009 - conforme mencionado no princípio deste artigo - dá-se início a campanha eleitoral e Lula estabelece clara relação entre capacidade de governar e capacidade de gerenciar:

Agora, o que eu estou percebendo é que a minha ministra da Casa Civil, a Dilma Rousseff, é a pessoa mais qualificada hoje para governar o Brasil. Ela coordena os principais programas de desenvolvimento no Brasil, ela conhece muito bem o Brasil, é uma gerente extraordinária, tem uma capacidade de gestão fantástica, conhece bem de Economia e eu acho que é uma mulher que tem uma história política que merece respeito. A companheira Dilma Rousseff foi militante de esquerda na década de 70, foi presa, foi torturada, e hoje ela é uma mulher preparada. Não tem mágoa do seu passado, não tem vergonha e, por isso, eu acho que ela está mais calejada para dar continuidade e melhorar aquilo que estamos fazendo hoje (03/2/09, sem local. Entrevista exclusiva por

142 REVISTA DEBATES, Porto Alegre, v.5, n.1, p. 139-162, jan.-jun. 2011. 
escrito ao jornal Extra) (LULA apud KAMEL, 2009, p. 248, grifos nossos) $)^{3}$.

De modo curioso, a matéria intitulada Lula dá nova versão para adiamento do início do PAC, publicada pelo jornalista Leonencio Nossa, da Agência Estado, em 7 de agosto de 2009, informa-nos que o lançamento do PAC era claramente trabalhado como estratégia eleitoral ${ }^{4}$ :

O presidente Luiz Inácio Lula da Silva apresentou hoje uma nova versão para o fato de ter adiado de um ano para outro de 2006 para 2007 - o lançamento do Programa de Aceleração do Crescimento (PAC), que hoje é a principal bandeira de seu governo. No encerramento de um seminário sobre desenvolvimento social, Lula afirmou que a mudança na data de lançamento do PAC aconteceu porque aceitou orientação de "um companheiro da área de comunicação". Segundo o presidente, esse companheiro lhe disse, em 2006: "Presidente, o senhor não vai precisar disso (do PAC) para ganhar a eleição. Deixe o PAC para depois, porque vão pensar que é eleitoreiro". O PAC foi lançado em janeiro de 2007, no início do segundo mandato de Lula. Na época, o próprio presidente disse, em diversas ocasiões, que tinha atrasado o anúncio para poder apresentar o projeto que considerava ideal e culpou ministros por não terem elaborado o PAC que ele desejava (NOSSA, 2009, s./p.,grifos nossos).

Fato é que o epíteto de mãe do $P A C$ passa a ser trabalhado e percebido como recurso eleitoral e, inclusive, alvo de críticas. Em 26 de agosto de 2009, Carlos Augusto Montenegro, presidente do Ibope e respeitado analista do cenário político nacional, em entrevista ao editor Alexandre Oltramari da revista Veja comenta: " 'Mãe do PAC', convenhamos, não é sequer uma boa sacada. As pessoas não entendem o que isso significa. Era melhor ter chamado a Dilma de 'filha do Lula' "(OLTRAMARI, 2009, p. 73, grifos nossos).

Cabe chamar a atenção para a potencialidade do recurso a esse epíteto na campanha. Dilma passa de Mãe do PAC para Mãe do povo. Como sublinha Thiollent (1986, p. 79) ao povo "associam-se frequentemente imagens de

\footnotetext{
${ }^{3}$ Em tal pronunciamento chama-nos a atenção o fato de Lula já ter elencado os argumentos que foram trabalhados posteriormente no HGPE de Dilma, o que nos sugere uma clareza, já nessa ocasião, em termos estratégicos da construção de sua imagem. O fato de que tal pronunciamento tenha tido origem em uma entrevista exclusiva por escrito ao jornal Extra corrobora, ainda mais, tal observação.

4 Ilustrativo mencionar que de acordo com Rodrigues (2010) inclusive as denominações dos projetos foram avaliadas em termos de eficácia, inclusive o Minha Casa, Minha Vida: "João Santana foi o criador de algumas das marcas mais famosas do lulismo, como o PAC (Programa de Aceleração do Crescimento) e o Minha Casa Minha Vida (cujo nome inicial proposto pela burocracia do governo era o anódino "Casa para Todos").
} 
humildade, pobreza e, ao mesmo tempo, grandeza ou invencibilidade". Thiollent, referenciando-se a Souza Filho (1984), ressalta:

\begin{abstract}
Como bem observou o autor, o termo "povo" possui ambigüidades ao nível do que designa. Em certos casos designa uma entidade demográfica ou antropológica, noutros casos designa as classes sociais de baixa renda. Em certos casos, é confundido com o conjunto da nação, noutros casos designa um subconjunto da população oposto à camada privilegiada. Essas ambigüidades são reproduzidas nos discursos políticos em função das circunstâncias e dos interesses expressados pelos oradores. Num mesmo discurso, um homem político pode utilizar diversas noções de povo. [...] Em conclusão podemos considerar que, dentro do discurso político, a aparente "referência" ao povo não pode ser interpretada como referência efetiva. A palavra "povo" não se refere a uma entidade concreta, sem referência de valores ou intenções políticas. A "referência" ao povo faz parte de um procedimento argumentativo de tipo apelativo no plano emocional (THIOLLENT, 1986, p. 85, grifos nossos).
\end{abstract}

Nesse sentido, é ilustrativo um trecho do discurso proferido por Lula em 23 de dezembro de 2005, em Osasco, São Paulo, em evento comemorativo do alcance da meta do programa Bolsa Família de 8.700.000 famílias atendidas. Nesse discurso, o termo povo é utilizado no sentido de um subconjunto da população oposto à camada privilegiada: "E, aí, a gente vai poder dizer ao povo brasileiro: 'Valeu a pena a gente acreditar que um igual a nós poderia fazer mais por nós do que os tantos diferentes que nós tivemos governando este país" "(LULA apud KAMEL, 2009, p. 558, grifos nossos). Para além do que tal recurso significa em termos de representação política, é oportuno mencionar que Lula teve que promover uma mudança em seu uso de modo a adequá-lo à situação de campanha de 2010. No dia 30 de setembro, último dia de campanha do primeiro turno, no desfecho do HGPE televisivo de Dilma, Lula, investido da autoridade de presidente - sentado em seu gabinete, de terno e com insígnia da Presidência na lapela - diz em tom solene:

Você que acredita em mim e acha bom o meu governo. Não tenha dúvida. Vote na Dilma. Igual a mim, a Dilma gosta dos pobres, respeita a vida, a paz, a liberdade e as religiões. Votar na Dilma é votar em mim com certeza de um governo ainda melhor. Hoje o Brasil está em outro patamar. O governo trabalha com velocidade e com Dilma nada vai parar. Ela é a certeza do Brasil seguir mudando.

Por fim, cabe mencionar como a Folha de S. Paulo, em editorial publicado em 17 de setembro de 2010, intitulado $A$ grande família, denuncia a

144 REVISTA DEBATES, Porto Alegre, v.5, n.1, p. 139-162, jan.-jun. 2011. 
estratégia de marketing de atribuir o epíteto de Mãe do povo a Dilma: "Há tempos o país vem assistindo à modelagem da figura pública da postulante petista pelo presidente da República e seus propagandistas. [...] Lula, em mais uma de suas sintomáticas e infelizes metáforas, empenha-se em entronizar (sic) como a 'mãe' do país" (s./p., grifos nossos). Observa-se aqui que o jornal não se atém ao detalhe de que na campanha Dilma é apresentada como Mãe do povo e não de Mãe do país. Como se verá adiante, em termos retóricos, é de fundamental importância considerar que ela cuidará do povo e não do território.

\title{
A arte de governar para Lula
}

No período oficial de campanha, chamou-nos atenção a resposta dada por Dilma, em entrevista ao jornal El País do dia 19 de junho de 2010. À pergunta: "Se a senhora ganhar, seguirá o modelo político de Lula?", responde:

\begin{abstract}
Vou continuar o modelo de Lula, mas com coração e alma de mulher. Não para repetir, mas para progredir. Para mim, a mulher tem uma grande capacidade de cuidar e ao mesmo tempo de estimular. É claro que o homem também pode ser cuidadoso, mas o olhar feminino é diferente. O programa de assistência Bolsa Família [as famílias recebem dinheiro em troca de que as crianças vão à escola e se vacinem], por exemplo, é administrado pela mãe. Em primeiro lugar porque ela tem um papel chave na coesão da família. E em segundo porque [...] Por acaso você conhece uma mãe que, se the derem dinheiro, não o destinará ao bem-estar de seus filhos? Difícil, não? No Brasil, uma das maiores tarefas pendentes é a recomposição dos laços. Melhorar a situação econômica não basta, também é preciso reconstruir a família, porque é chave para melhorar a educação, combater a criminalidade [...]. Definitivamente, para crescer como sociedade. Esta recomposição dos laços familiares deve ser colocada no centro da agenda política. E não é tarefa para um mandato, mas de muitos anos de trabalho [...]. No Brasil, privilegiar a mulher não é uma política de gênero, é uma política social: $30 \%$ das famílias brasileiras são encabeçadas por mulheres; $52 \%$ da população somos mulheres e os $48 \%$ restantes são nossos filhos. Não se trata de criar um matriarcado, mas de dar à mulher a importância que tem para a estrutura familiar. Lula tem muita sensibilidade para esse tema, ele foi criado por uma mulher forte (MATOS, 2010, s./p., grifos nossos).
\end{abstract}

Nessa resposta da então candidata percebe-se claramente a articulação que se pretende estabelecer neste artigo entre a metáfora mãe do povo e o lulismo. Entendido aqui conforme propõe Ricci (2010, p. 18-19) "como modelo gerencial do Estado brasileiro [...], como engenharia política", 
como paradigma de governabilidade. E que tem Lula como protagonista. Para tanto, a seguir, busca-se apresentar como, discursivamente, Lula expõe esse modelo.

Por meio de um levantamento feito no Dicionário Lula: Um presidente exposto por suas próprias palavras, de Ali Kamel (2009), busca-se, a seguir, apresentar - com base nos discursos de Lula, proferidos entre 2003 e 2009 os sentidos que ele confere ao que venha ser governar. De modo instigante, se observará, mais adiante, como tais sentidos podem ser examinados à luz da análise genealógica do Estado empreendida por Michel Foucault ao estudar as práticas de governo ou a governamentalidade.

De início, é elucidativa a proposta de Lula de substituir a palavra governar por cuidar:

\begin{abstract}
Eu vou tentar não utilizar mais a palavra "governar", porque "governar" é muito pomposa. Eu vou utilizar a palavra "cuidar". Eu preciso cuidar do Brasil e cuidar do povo brasileiro. A palavra mais adequada, Júlio [padre Júlio Lancellotti, coordenador do Vicariato do Povo de Rua da Arquidiocese de São Paulo], é cuidar. Nós temos que cuidar dessa gente, temos que cuidar desse povo esperançoso (23/12/06 - São Paulo - Cerimônia de Natal da Vida e Cidadania dos Catadores e da População em Situação de Rua) (LULA apud KAMEL, 2009, p. 348, grifos nossos).
\end{abstract}

Importa ressaltar que embora tal proposta de substituição tenha sido feita em uma cerimônia dessa natureza e para esse público específico é o uso do termo cuidar que possibilita a Lula dar centralidade à mulher-mãe, bem como, dotar a prática de governar de uma dimensão mais afetiva na medida em que para ele quem sabe cuidar por excelência é a mãe. Nesse sentido, não surpreende o fato de o verbete governar remeter para o verbete Lindu, dona (mãe de Lula), além da remissão a adversário. No verbete dona Lindu são apresentados trechos de discursos nos quais Lula relata a vida de sua família como retirantes nordestinos e a coragem e o heroísmo de sua mãe:

[...] por conta dos compromissos que ela tinha com seus filhos, ela criou os oito filhos, todos aprenderam uma profissão, todos casaram e um chegou até a presidente da República deste país (02/02/05, Gurulhos - SP. Entrega de cartões do programa Bolsa Família) (LULA apud KAMEL, 2009, p. 412).

Do verbete mãe(s) transcreve-se, abaixo, trechos de dois discursos proferidos por Lula que se consideram particularmente significativos para a reflexão ora encaminhada. Ressalta-se no primeiro o entendimento dele de que cumprir a função de mãe independe do sexo e, no segundo, uma valorização da capacidade da mulher como mãe e mesmo como presidente. 
Note-se, aqui, que ele, em 2005, ainda não estava em campanha para Dilma $^{5}$, mas reportava-se às mulheres como teve que fazer no período eleitoral quando sua candidata precisava assegurar uma margem maior de votos válidos entre mulheres e consolidar os votos femininos que estavam ainda voláteis em data bem próxima ao pleito.

O Brasil, todos vocês sabem, é um país que trata de forma desigual a sua população. E qual é a tarefa que nós temos que fazer? Como nunca existe dinheiro para fazer tudo, eu sempre digo que um governante tem que se comportar como uma mãe, porque nada no mundo é mais justo do que ela. Se uma mãe tiver, na sua casa, três crianças para comer e tiver três bifes, podem ficar certos de que nenhuma mãe vai deixar uma criança comer dois bifes e a outra ficar sem nenhum [...] (06/05/03, Aracaju - SE. Outorga da medalha de mérito Serigy) (LULA apud KAMEL, 2009, p. 439, grifos nossos).

Eu estou dizendo isto para mostrar que o papel de um presidente da República não é diferente do papel que vocês exercem dentro da casa de vocês. Muitas vezes vocês estão em casa, pensam que é muito diferente de ser presidente. Não é. É igual às decisões que vocês têm que tomar em casa. Uma mãe, quando está com seus dois filhos dentro de casa, que o filho começa a brigar com o outro - e quem tem menina sabe como é que menina briga dentro de casa -, ela tem que tomar posição, e não pode ficar do lado de um e prejudicar o outro. A mãe sempre tem que ter o papel de harmonizar, de manter o equilíbrio, para que haja harmonia dentro de casa. Esse é o papel que um presidente da República exerce (08/03/05, Apodi - RN. Cerimônia por ocasião do Dia Internacional da Mulher) (LULA apud KAMEL, 2009, p. 438-439, grifos nossos).

Também fica claro que, para Lula, governar é como criar uma família:

É por isso que sempre trato a arte de governar como a arte de criar uma família. Parece fácil criar uma família, mas o mundo está cheio de irresponsáveis, homens ou mulheres que não conseguem criar uma família. Está cheio de gente

5 No dia 21 de agosto de 2010, é reproduzido no blog Mulheres com Dilma (Disponível em: <http://www.mulherescomdilma.com.br/?p=6409>; acesso em: 23 ago. 2010) em post intitulado Esta eleição vai dignificar a mulher um trecho interessante do discurso de Lula em um comício realizado em Osasco, São Paulo: "Qual é o preconceito que a gente pode ter contra uma pessoa que ensinou a gente a comer quando a gente nem sabia pegar numa colher? Qual é o preconceito que a gente tem contra uma pessoa que perdeu horas e horas para ensinar a gente a andar? Qual é o preconceito que a gente pode ter contra uma pessoa que nos deu o caráter, porque quem dá o caráter não é o pai, é a mãe? Qual é o preconceito que a gente pode ter contra uma pessoa que significa algo tão sagrado na sociedade, como a mulher? Tão importante que só ela pode procriar". 
que não consegue cuidar da educação correta dos filhos, que não consegue fazer o mínimo necessário que todos nós deveríamos fazer e muitas vezes não fazemos. Então, o desafio de governar é exatamente esse, é a gente poder fazer as coisas simples com a precisão que a sociedade precisa, fazer com que o Estado esteja a serviço da comunidade e não a serviço de uma minoria [...] (LULA apud KAMEL, 2009, p. 347 , grifos nossos).

E, por fim, esclarece sobre como um governante, em sua opinião, deve olhar para a nação:

[...] Digo sempre que cada um de nós, sobretudo o Governo, precisa olhar para o povo como se estivesse olhando para o seu próprio filho ${ }^{6}$. E quando uma mãe responsável ou um pai responsável olha para os seus filhos, ele pode até dizer para o filho: "Olhe, eu não posso fazer tudo o que você quer, mas você tem que ter a certeza de que eu estou fazendo tudo o que posso fazer para atender e lhe dar aquilo que você merece de melhor" (25/02/03, Brasília - DF. Reunião do Conselho Nacional de Segurança Alimentar e Nutricional Consea) (LULA apud KAMEL, 2009, p. 438).

Pelo exposto, observa-se que Lula apresenta sua visão de governo a partir de sua vivência que encontra eco na teoria clássica do empiricismo que "parte do princípio de que todo conhecimento decorre da experiência concreta, portanto resultante de uma ação externa sobre o cérebro humano, sendo que as percepções sobre o mundo seriam captadas pelos órgãos dos sentidos" (MARANHÃO, 2000, p. 119), ou seja, explicações dadas ao plano do sensível: "um governante tem que se comportar como uma mãe" ou "o Governo tem que olhar para o povo como se estivesse olhando para seu próprio filho".

Cabe sublinhar que este recurso de buscar apreender a - singular visão de Lula sobre governo de Estado, por meio da articulação de verbetes apresentados por Kamel (2009), possibilitou-nos uma visão de conjunto sobre seus discursos que, por sua vez, surpreendeu-nos por sua clara conexão com um tipo de modelo de governo específico - o da família - formulado por autores que produziram uma literatura anti-Maquiavel, literatura essa recuperada por Foucault (1979) e não referenciada habitualmente nos estudos sobre construção de imagem pública política.

De início, Foucault (1979, p. 279) esclarece que nessa literatura

\footnotetext{
6 Também é oportuno mencionar uma fala de Lula sobre como deve ser o comportamento do filho para com sua mãe: "A mãe é quase que uma coisa sagrada. Todo dia de manhã nós temos que levantar e perguntar a nós mesmos se nós fizemos algum gesto bom para a nossa mãe, se nós fomos obedientes, se nós a tratamos com carinho, se nós tratamos bem o nosso pai. Essa relação é condição fundamental para a gente vencer na vida" (30/03/07, Olinda - PE. Formatura do programa ProJovem) (LULA apud KAMEL, 2009, p. 438).
}

148 REVISTA DEBATES, Porto Alegre, v.5, n.1, p. 139-162, jan.-jun. 2011. 
sem dúvida encontramos uma espécie de retrato negativo do pensamento de Maquiavel, em que se representa um Maquiavel adverso. O Príncipe, contra o qual se luta, é caracterizado por um princípio: o príncipe está em relação de singularidade, de exterioridade, de transcendência em relação ao principado; recebe o seu principado por herança, por aquisição, por conquista, mas não faz parte dele, lhe é exterior $[\ldots]$.

Segundo Foucault o corolário desse princípio é que ao configurar-se como uma relação de exterioridade "ela é frágil e estará sempre ameaçada, exteriormente pelos inimigos do príncipe que querem conquistar ou reconquistar seu principado e internamente, pois não há razão a priori para que os súditos aceitem o governo do príncipe" (FOUCAULT, 1979, p. 279). Assim, o exercício do poder do príncipe implicará sempre uma preocupação com o território e com os súditos, em outras palavras, o principado não é entendido como um conjunto formado pelos súditos e o território. Nesse sentido, sublinha o autor: "o Príncipe de Maquiavel é essencialmente um tratado da habilidade do príncipe em conservar seu principado e é isto que a literatura anti-Maquiavel quer substituir por uma arte de governar. Ser hábil em conservar seu principado não é de modo algum possuir arte de governar" (FOUCAULT, 1979, p. 280).

Como salientado anteriormente, vale lembrar que no âmbito desta discussão, interessa-nos destacar como a visão, a seguir do que venha a ser governante e a arte de governar está em consonância com a percepção apresentada por Lula e depois por Dilma.

Foucault (1979) sublinha que para Guillaume de La Perrière ${ }^{7}$, dentre outros, o governante não é visto apenas como o príncipe em seu principado como para Maquiavel - "[...] muita gente pode governar: o pai de família, o superior do convento, o pedagogo e o professor em relação à criança e ao discípulo" (FOUCAULT, 1979, p. 280, grifos nossos). Também a arte de governar não é exclusiva: "[...] também se diz governar uma casa, almas, crianças, uma província, um convento, uma ordem religiosa, uma família" (FOUCAULT, 1979, p. 280, grifos nossos). Entretanto, para os autores, dentre as diversas formas de governo "que se cruzam, que se imbricam no interior da sociedade e do Estado" privilegia-se a arte de governar adequadamente uma família (FOUCAULT, 1979, p. 280, grifos nossos). Retomando o artigo Economia Política de Rousseau, do século XVIII, Foucault (1979, p. 281) ressalta:

7 Em seu texto Foucault esclarece que "para caracterizar esta arte de governar, examinarei o Miroir politique contenant diverses manières de gouverner de Guillaume de La Perrière, um dos primeiros textos desta literatura anti-Maquiavel, que apresenta alguns pontos importantes" (FOUCAULT, 1979, p. 280). 
Governar um Estado significará portanto estabelecer a economia [isto é, a maneira de gerir corretamente os indivíduos, os bens, as riquezas no interior da família] ao nível geral do Estado, isto é, ter em relação aos habitantes, às riquezas, aos comportamentos individuais e coletivos, uma forma de vigilância, de controle tão atenta quanto a do pai de família (FOUCAULT, 1979, p. 281, grifos nossos).

E, ainda: "governar uma casa, uma família, não é essencialmente ter por fim salvar as propriedades da família; é ter como objetivo os indivíduos que compõem a família" (FOUCAULT, 1979, p. 283). E, por fim, entre as características de um bom governante, apontadas pelos autores desta literatura, destaca-se a diligência:

Diligência: aquilo que faz com que o governante só deva governar na medida em que considere e aja como se estivesse ao serviço dos governados. E La Perrière se refere mais uma vez ao exemplo do pai de família, que é o que se levanta antes das outras pessoas da casa, que se deita depois dos outros, que pensa em tudo, que cuida de tudo pois se considera a serviço da casa. Vê-se como esta caracterização do governo é diferente da caracterização do príncipe que encontra ou que se pensava encontrar em Maquiavel (FOUCAULT, 1979, p. 285, grifos nossos).

No entanto, como esclarece Foucault, o modelo de família, como modelo de governo, é eliminado quando da emergência do governo da população e isso ocorre

a partir do momento que a população aparece como absolutamente irredutível à família, esta passa para um plano secundário em relação à população, e portanto não mais como modelo, mas como segmento. E segmento privilegiado, na medida em que, quando se quiser obter alguma coisa da população - quanto aos comportamentos sexuais, à demografia, ao consumo, etc. - é pela família que se deverá passar. De modelo, a família vai tornar-se instrumento, e instrumento privilegiado, para o governo da população e não modelo quimérico para o bom governo. Este deslocamento da família do nível de modelo para o nível de instrumentalização me parece absolutamente fundamental, e é a partir da metade do século XVII que a família aparece nessa dimensão instrumental em relação à população, como demonstram as campanhas contra a mortalidade, as campanhas relativas ao casamento, as campanhas de vacinação, etc. Portanto, aquilo que permite à população desbloquear a arte de governar é o fato dela eliminar o modelo da família (FOUCAULT, 1979, p. 289 , grifos nossos).

150 REVISTA DEBATES, Porto Alegre, v.5, n.1, p. 139-162, jan.-jun. 2011. 
Eliminado como modelo inteligível; permanece como modelo sensível, como retórica político-eleitoral. Visualiza-se, aí, a presença - e a força - da retórica, de natureza ficcional, de um mundo futuro possível ${ }^{8}$, melhor que 0 atual; um "modelo quimérico para o bom governo" (FOUCAULT, 1979, p. 289).

\section{Mãe do povo brasileiro: estratégia sensível de campanha}

Muniz Sodré, em seu livro intitulado As estratégias sensíveis: afeto, mídia e política define "estratégias sensíveis" como "jogos de vinculação dos atos discursivos às relações de localização e afetação dos sujeitos no interior da linguagem" (SODRÉ, 2006, p. 10). Nessa obra, interessa-Ihe, sobretudo, examinar a preponderância da estesia, da estética, na esfera da mídia. "Estética ou estesia são de fato designações aplicáveis ao trabalho do sensível na sociedade. É um trabalho feito de falas, gestos, ritmos e ritos, movido por uma lógica afetiva em que circulam estados oníricos, emoções e sentimentos" (SODRE, 2006, p. 46). Diz ainda o autor: "o afeto ganha o primeiro plano como potencial interativo e operatório do marketing" (SODRÉ, 2006, orelha). $O$ que pode ser bem exemplificado com a indagação formulada pelo marqueteiro João Santana, por ocasião de uma entrevista concedida ao jornal Folha de S. Paulo, em 2006, logo após a reeleição de Lula: "vivemos numa sociedade ambientada pela mídia, onde as formas políticas se modificaram e o discurso é outro. Hoje, o meu corpo, o meu afeto e minha relação afetiva e sexual passam pelo mundo da mídia. Porque a política não passaria por aí?" (SANTANA apud RODRIGUES, 2006, s./p.). A seguir, busca-se demonstrar, como a propaganda eleitoral de Dilma passou por aí, no cinema, especificamente, no filme Lula, o filho do Brasil ${ }^{9}$ e, na televisão, no HGPE televisivo da candidata.

\footnotetext{
${ }^{8}$ Figueiredo et al (2000) sistematizaram uma metodologia de análise das campanhas eleitorais que consiste em um estudo da retórica política da situação e da oposição a partir da identificação de mundos possíveis: atual e futuro. A descrição do mundo atual, pelo político, faz parte de uma construção operada a partir de inferências sobre o mundo real e a descrição do mundo futuro é de natureza ficcional, ou seja, o político busca persuadir a partir da formulação de um mundo futuro possível.

${ }^{9}$ Cabe informar que este tópico foi elaborado pelas alunas Bárbara Fernanda Gonçalves Arruda de Brito Ribeiro, Fabiana Freitas de Paula, Gabriela Merley Oliveira Fernandes, Kenia Roberta Rego Silva e Marina Guitti Bessa, do oitavo período do Curso de Publicidade e Propaganda, da Pontifícia Universidade de Minas Gerais, que estão desenvolvendo um trabalho sob minha orientação intitulado Construção da imagem pública política no cinema: uma análise do filme 'Lula, o filho do Brasil'.
} 


\section{Dilma $^{10}$ \\ Filme Lula, o filho do Brasil: A arma cinematográfica de Lula e}

O filme Lula, o filho do Brasil, dirigido por Fábio Barreto e produzido por Luiz Carlos Barreto (LC Barreto), foi estreado no dia $1^{\circ}$ de janeiro de 2010 - portanto, antes do lançamento oficial da pré-candidatura de Dilma pelo PT, em fevereiro. O roteiro do filme, escrito por Denise Paraná, Daniel Tendler e Fernando Bonassi, foi filmado em dois estados (Pernambuco e São Paulo), sete cidades e 70 locações, no período compreendido entre 20 de janeiro e 18 de março de 2009. Custou aproximadamente 16 milhões de reais - o mais caro da história do cinema brasileiro até aquele momento - deste total, 12 milhões foram gastos para a produção (do início do roteiro até a finalização) e 4 milhões destinados às campanhas de lançamento e distribuição das cópias em cerca de 400 salas de cinema (CASTELLón, 2009). De acordo com informações disponíveis no site do filme, os recursos captados para a produção de Lula não fizeram uso de leis de incentivo, nem de patrocínio de empresas estatais. Para Luiz Carlos Barreto, não seria adequado utilizar o dinheiro público para contar a vida de um presidente ainda em exercício ${ }^{11}$.

O filme Lula, o Filho do Brasil confere, já no próprio título, centralidade à figura materna. Tal relevância também se evidencia na abertura do filme, quando os primeiros nomes que aparecem nos créditos são os nomes das três atrizes que interpretam as principais mulheres da vida de Lula, sua mãe Dona Lindu (Glória Pires), sua primeira esposa Maria de Lurdes (Cléo Pires) e sua segunda e atual esposa Marisa Letícia (Juliana Baroni). Apesar de o filme atribuir importância às três mulheres, seu enredo gira em torno de uma só, Dona Lindu. O filme inicia-se com a imagem de Dona Lindu grávida e rodeada de filhos sendo abandonada por seu marido no sertão nordestino e termina com Lula em seu discurso de posse presidencial dedicando seu diploma de presidente a sua mãe, então falecida, quando uma faixa surge no meio da multidão com os dizeres: "Presidente! Dona Lindu está feliz". Cabe esclarecer que tem destaque no filme a morte de Dona Lindu, em 12 de maio de 1980, quando é possível perceber um salto desta data para o dia da posse de Lula,

\footnotetext{
10 Este subtítulo é uma reprodução literal do título da coluna de Elio Gaspari, publicada no jornal Folha de S. Paulo, no dia 15 de novembro de 2009. Dela destacamos alguns trechos indicativos da percepção do filme como arma de campanha e do tom crítico do colunista: "O filme [...] estreará em 500 cinemas no dia 10 de janeiro. As platéias chorarão de emoção e a oposição de raiva. [...] É possível que algumas comecem a chorar já na fila para a compra de ingressos. Deliberadamente épico, o filme arranca até a última lágrima da platéia. [...]. Só Deus sabe o tamanho do benefício que o sucesso do filme levará aos companheiros. Olhado sob esse prisma, é um exemplar de realismo petista. [...] Lula, o filho do Brasil ajudará, e muito, as campanhas de Dilma Rousseff e do PT. Se Luís Inácio Lula da Silva visse esse filme em 1968, quando era um peão que só pensava em futebol, votaria no PT, em Dilma e nos candidatos indicados por aquele filho porreta de Dona Lindu" (GASPARI, 2009, s./p.).

${ }^{11}$ Disponível em: <http://www.lulaofilhodobrasil.com.br/entrevistas\#LuizCarlosBarreto>. Acesso em: 12 fev. 2011.
}

152 REVISTA DEBATES, Porto Alegre, v.5, n.1, p. 139-162, jan.-jun. 2011. 
em 2002, cena de encerramento da cinebiografia. O produtor Luiz Carlos Barreto explica, em entrevista ao site do filme: "justamente pela importância que Dona Lindu teve na vida de Lula decidimos terminar o filme quando ela morre, em 1980"12. No entanto, de modo curioso, Denise Paraná, escritora do livro homônimo ${ }^{13}$ e corroterista do filme, em 2002, apresenta outra justificativa para tal corte temporal:

Nossa história tem início num pequeno vilarejo do sertão nordestino em 1945, ano de nascimento do pequeno Luiz Inácio, e tem seu fim em 1980, quando então Lula havia se tornado uma liderança de massa, figura pública respeitada nacional e internacionalmente. Nosso interesse é compreender como em determinadas circunstâncias objetivas colocadas pela vida, homens, a exemplo de Lula, são capazes de mudar seu destino, transformando seus parcos recursos em grandes armas de sobrevivência e ascensão social (PARANÁ, 2002, p. 22) ${ }^{14}$.

Já em entrevista à Folha de S. Paulo, em 27 de novembro de 2009, Denise Paraná esclarece que "é um filme para o povo ${ }^{15}$ e não para intelectuais [...] uma ficção com foco no drama familiar, na relação mãe e filho" (É UM FILME PARA O POVO, 2009, s./p., grifos nossos). Em entrevista a Oswaldo Luiz Colibri Vitta, da rádio Brasil Atual, Denise Paraná reitera tal propósito: "eu pedi [ao Barreto] que tinha que ser uma relação mãe e filho, tinha que

12 Disponível em: <http://www.lulaofilhodobrasil.com.br/entrevistas\#LuizCarlosBarreto>. Acesso em: 12 fev. 2011.

13 Interessante ressaltar que o livro Lula, o filho do Brasil publicado em 2002, com 527 páginas, pela Editora Fundação Perseu Abramo, entidade criada e mantida pelo PT, no ano da primeira eleição vitoriosa de Lula - resultado da tese de doutorado em Ciências Humanas defendida na USP, em 1995, intitulada Da cultura da pobreza a cultura da transformação - foi reescrito, em 2009, por Denise Paraná. Nesse sentido, chama a atenção a informação fornecida pela autora "Nesta madrugada de 13 de outubro de 2009, quando termino de escrever este livro [...]" (PARANÁ, 2009, p. 138) o que nos sinaliza que o filme não foi uma adaptação do livro de 2002. $\mathrm{Na}$ versão de 2009, com 139 páginas, lançada junto com o filme, a foto de Lula da versão anterior é substituída pelo cartaz do filme que dá centralidade à personagem de dona Lindu (Glória Pires).

${ }^{14}$ Também é oportuno comentar que neste livro é mencionado que "em 10 de fevereiro de 1980, Lula, junto a outros sindicalistas, intelectuais, representantes da igreja progressista, militantes de grupos de esquerda e de movimentos populares, entre outros, fundam o Partido dos Trabalhadores" (PARANÁ, 2002, p. 28). No filme, no entanto, não é feita nenhuma menção ao PT; nem a este fato histórico. Tal silenciamento - muito significativo - sugere-nos uma possível intenção de fortalecimento do lulismo.

${ }^{15}$ Importa ressaltar que esta pretensão pode ser percebida no gênero escolhido. O diretor Fábio Barreto afirmou que "queria fazer um melodrama épico" (BARRETO apud MIRANDA, 2009, s./p.). Tal propósito pode ser percebido na construção do roteiro que apresenta uma estrutura narrativa linear, fundamentada em uma série de incidentes que ocorrem na vida do personagem, assemelhando-se ao folhetim. De acordo com Martín-Barbero (2006, p. 189): "o folhetim se dirige às mesmas pessoas sobre as quais discorre". 
ser uma história de família. Que é muito mais universal e interessante que uma história de um candidato político".

Também nessa entrevista radiofônica, Denise Paraná menciona a centralidade dada à personagem de Dona Lindu no filme:

Denise: Declaro meu amor pela Dona Lindu, porque ela é um exemplo de grandeza. E a Dona Lindu se repete em milhões de outras mulheres e homens que são generosos.

Oswaldo: Ela é a figura central?

Denise: Central. Mais do que o Lula.

Luiz Carlos Barreto, diretor do filme, em entrevista ao site de lançamento do filme ${ }^{16}$ vai além e diz que:

\begin{abstract}
A ideologia de Lula foi extraída dos ensinamentos da mãe, que tinha um lado pragmático que ele também apresenta. Ela era uma mãezona, cujo lema de vida, quase um bordão era 'nessa família não vai ter nem bandido nem prostituta'. [...] Imagino que o livro seja uma espécie de Bíblia para o Lula, que ele de vez em quando consulta, às escondidas, para reencontrar as palavras da Lindu ${ }^{17}$.
\end{abstract}

As principais características atribuídas à Dona Lindu no filme são sua força, é uma mulher batalhadora que cria praticamente sozinha seus oito filhos, não se abate com o abandono sofrido pelo marido e nem com as adversidades da vida; sua fé quando acredita sempre que seus filhos são capazes e os incentiva sempre a estudar e a aprender uma profissão que thes garanta um futuro melhor; sua determinação e persistência, Lindu não demonstrava medo ao enfrentar os desafios que a vida lhe impunha, apesar das dificuldades que passava nunca reclamava da situação. Em todos os momentos importantes na vida de Lula, retratados no filme, Lindu aparece presente seja o aconselhando, o incentivando, o admoestando ou simplesmente sentindo orgulho de cada conquista do filho. Lindu é retratada como um exemplo de mãe que cuida com carinho de seus filhos em todas as fases de suas vidas. Quando crianças, em uma das cenas iniciais, no trajeto de migração para São Paulo, acontece um acidente em que uma criança morre durante a viagem, Lindu poupa seus filhos de que vejam a garota sendo enterrada à beira da estrada protegendo-os de um possível trauma. Como a maioria das mães, Lindu ainda se preocupava com seus filhos já em fase adulta e continuava dedicando-se a cuidar deles, como vemos na cena em que ela vai até o cais, onde seus filhos trabalhavam, levando-Ihes almoço e incentivando-Ihes a lutar contra as dificuldades impostas pela vida de

\footnotetext{
16 Disponível em: <http://www.lulaofilhodobrasil.com.br>. Acesso em: 12 fev. 2011.

17 Disponível em: <http://www.lulaofilhodobrasil.com.br/entrevistas\#LuizCarlosBarreto>. Acesso em: 12 fev. 2011.
}

154 REVISTA DEBATES, Porto Alegre, v.5, n.1, p. 139-162, jan.-jun. 2011. 
imigrante. Dona Lindu jamais aparece agredindo seus filhos, pelo contrário, os protege das agressões do pai. Quando percebe que o comportamento do pai está prejudicando o crescimento de seus filhos, opta por ir embora, abandonando seu marido agressor.

Em uma cena do filme, há uma tentativa de aproximar Dona Lindu à imagem da Virgem Maria, quando ela aparece amamentando Lula. A estrutura da cena, seu corte e sua luz aludem às representações artísticas da Virgem segurando o Menino Jesus em seus braços. Esta cena sugere Dona Lindu como uma mãe iluminada e escolhida para gerar um eleito de Deus para lutar por seu povo. Nesse sentido, também a cena em que Lindu ergue seu filho, ainda bebê, aos céus e o batiza como Luiz Inácio, fornece indícios de que ela estaria o consagrando, como se ele fosse uma criança predestinada.

Em dezembro de 2009, Denise Paraná, em entrevista concedida a Oswaldo Vitta, veiculada no jornal da rádio Brasil Atual, sugere-nos os mecanismos de identificação pretendidos por meio da construção da imagem de Dona Lindu e faz transparecer a força do apelo emocional quando se recorre à figura materna:

Você deve ter ouvido uma frase que é até bem conhecida que se diz que se conhece uma árvore pelos frutos. E os filhos da Dona Lindu, os frutos dela, nos dizem como ela era, essa mulher era absolutamente especial, porque ela montou uma família, que embora traduza infinitas famílias brasileiras, incontáveis famílias, é tudo muito típico do Brasil. Ela era muito especial.Quando eu comecei a entrevistar os filhos [para elaboração do livro] todo mundo quando falava nela chorava, o Lula, então, é uma choradeira para falar da mãe. [...] Eu falei: Puxa, todo mundo gosta da mãe, de um modo geral, todo mundo gosta da mãe, mas essa mãe, depois o que acontece é que eu, quando pedem para eu falar dela, eu fico emocionada (PARANÁ apud VITTA, 2009, s./p.).

Interessante, ainda, salientar que o filme também pode ser visto como retrato do povo brasileiro: Lula, como outros, filho do Brasil. Nessa perspectiva, é ilustrativa a declaração dada por Denise Paraná em uma entrevista ao site do filme: "Estamos mostrando o Brasil e seu povo numa história real de superação. Se Lula é um personagem único, de uma trajetória jamais vista, ao mesmo tempo sua experiência pessoal é a repetição da biografia de incontáveis brasileiros ${ }^{\prime 18}$. Nesse sentido, é interessante mencionar como no HGPE de Dilma ganham centralidade relatos emocionados - de superação de diversos e anônimos brasileiros e brasileiras; aclamados em música, recorrente nos programas, como gente guerreira.

\footnotetext{
18 Disponível em: <http://www.lulaofilhodobrasil.com.br/entrevistas\#DeniseParana>. Acesso em: 12 fev. 2011.
} 
Por fim, como se verá a seguir, acredita-se que, na campanha, tentouse colar não só a imagem de Dilma a Lula, mas também, a imagem dela a essa carismática imagem específica de mãe: Dona Lindu. De acordo com João Santana, na campanha, buscava-se mais que um voto racional: "Tínhamos o desafio de transformar em voto direto, e apaixonado, uma pessoa que chegava à primeira cena por força de uma escolha indireta [...] tínhamos a missão de fazer Dilma conhecida e ao mesmo tempo amada" (SANTANA apud RODRIGUES, 2010, s./p., grifos nossos).

Em face ao exposto, pergunta-se: oferecer Dilma como Mãe do povo brasileiro teria sido a fórmula encontrada para apresentá-la como portadora de uma força própria, de carisma, e, assim, equilibrar a presença de Lula na campanha? Afinal, como bem assinalou João Santana: "tínhamos um presidente, em final de mandato, com avaliação recorde, paixão popular sem limite e personalidade vulcânica [...] tínhamos de transformar a força vulcânica de Lula em fator equilibrado de transferência de voto, com o risco permanente da transfusão virar overdose e aniquiliar o receptor" (SANTANA apud RODRIGUES, 2010, s./p.). Cabe aqui lembrar que, no segundo semestre de 2009, com base nos altos índices de aprovação do presidente Lula, era frequente na mídia, de um modo geral, a preocupação com a possibilidade de Lula fazer seu sucessor. Nessa ocasião, chamou-nos a atenção uma análise formulada pelo especialista em marketing político e sociólogo Antônio Lavareda em entrevista concedida à revista Isto é:

\begin{abstract}
É óbvio que um presidente bem avaliado consegue transferir uma dose substancial de prestígio para seu candidato. Mas isso não significa necessariamente que ele consiga transmitir a porção substancial do vínculo que construiu com 0 eleitorado. Lula tem um vínculo emocional com o eleitor brasileiro. É mais fácil transferir prestígio do que vínculos emocionais. Quanto ao prestígio, basta dizer: "Olha, a minha candidata foi um personagem importante no meu governo". Outra coisa é transferir afeto que a população dedica a Lula, sobretudo os mais pobres. É muito difícil transferir afeto (LAVAREDA apud COSTA e MARQUES, 2009, s./p., grifos nOSSOS).
\end{abstract}

Entretanto, o que se observou com a produção do filme, no HGPE e nos discursos proferidos por Lula em eventos políticos - tanto os de campanha quanto aqueles anteriormente apresentados - é que o então presidente da República não se limitou a dizer: "Olha, a minha candidata foi um personagem importante no meu governo". Nessa perspectiva, também é muito ilustrativa a resposta dada por Dilma Rousseff, no dia 19 de junho de 2010, ao jornal El País. À pergunta: "A senhora não teme que a sombra de Lula prejudique sua carreira?", Dilma responde: "Sou a ministra da Casa Civil. Sou quem coordena os ministros e os principais projetos de governo. Trabalhei intimamente com o presidente Lula nos últimos cinco anos e meio. 
O sucesso dele é o meu. Fui seu braço direito e esquerdo" (MATOS, 2010, s./p., grifos nossos).

\section{HGPE - $1^{\circ}$ turno: em busca do afeto}

Ao longo dos programas do HGPE de Dilma Rousseff foram identificadas diversas alusões ao epíteto Mãe do povo. O primeiro programa do Horário Gratuito Político Eleitoral (HGPE) - momento crucial de posicionamento de imagem da candidata - termina com um jingle que diz em sua letra, representando Lula: "Agora as mãos de uma mulher vão nos conduzir / Eu sigo com saudade, mas feliz a sorrir / Pois sei, o meu povo ganhou uma mãe / Que tem um coração que vai do Oiapoque ao Chuí". Ainda nesse programa, Dilma diz: "Quero fazer com cuidado de mãe o que precisa ainda ser feito. Este é o meu sonho".

Em quase todos os programas é reprisado um clipe feito com mulheres de todas as idades e etnias e que tem como trilha sonora uma música que tem a seguinte letra:

Mulheres são fortalezas divinas / são belas bailarinas / são preto no branco guerreiras de fé / mulher / mulheres são pulso firme / mas com voz e o amor de mãe / são predestinadas a vencer / assim é a mulher / contra a insegurança / mulheres / a favor do Brasil / a favor da ordem / a favor do progresso / queremos mulher.

A alusão a Dilma como mãe do povo também aparece no depoimento de uma costureira, Marilane Dantas, reproduzido em vários programas, por exemplo, no veiculado no dia 26 de agosto:

A comunidade chama Lula de pai. Porque realmente foi um homem que se preparou para isso. Para dirigir o seu país, mas pensando na igualdade, pensando na classe lá embaixo. Ele entrou com essa luz para os pobres. Está entendido. O pai do povo é ele [Lula]. E espero que a Dilma Rousseff seja a mãe do povo.

O mote da campanha é a ideia de mudança. O Brasil mudou com Lula e quer seguir mudando. A esse respeito é significativa a fala de Dilma:

[...] Para você achar que tem de mudar o seu país. Você tem que ter uma relação afetiva com seu povo também, ou seja, tem que te incomodar afetivamente também, não é só racionalmente, afetivamente a pobreza. Afetivamente, criança sem recurso. E a mim sempre tocou afetivamente uma coisa 
que eu vi, a humildade do povo (HGPE do dia 19 de agosto de 2010).

O carinho de mãe pode ser percebido na produção que foi feita para que se desse a impressão de que Lula e Dilma estavam dando um abração no Brasil. No primeiro programa Dilma apresenta-se como se estivesse no Chuí e Lula no Oiapoque e um diálogo se estabelece entre eles:

Dilma: É muito bom começar essa campanha aqui nas margens do Chuí, onde acaba e, ao mesmo tempo, começa o Brasil.

Lula: E é muito bom Dilma lhe responder da nossa região Norte. Onde o Brasil também começa e termina. [...] Desse jeito nós podemos dar um abração no nosso povo. Um abração do tamanho do Brasil. E anunciar o início de um novo tempo.

Também é muito significativa a referência à característica da diligência que deve se fazer presente em um bom governante. Conforme mencionado anteriormente aquele exemplo "do pai de família, que é o que se levanta antes das outras pessoas da casa, que se deita depois dos outros, que pensa em tudo, que cuida de tudo, pois se considera a serviço da casa" (FOUCAULT, 1979 , p. 285, grifos nossos). Lula no primeiro HGPE:

\footnotetext{
Na primeira noite que eu passei no Alvorada. Eu pedi a Deus que eu começasse e terminasse bem o meu governo. Além de uma excelente equipe eu tive uma chefe de equipe maravilhosa, a Dilma. Ela foi parceira em todos os momentos. Aqui mesmo nessa sala ficamos até tarde da noite buscando soluções para o Brasil.
}

De acordo com Maranhão, "o ato de cuidar está sujeito também à capacidade daquele que cuida de interagir com o outro, de identificar suas necessidades, capacidade construída no interior da cultura" (MARANHÃO, 2000 , p. 120, grifos nossos). Nesse sentido, é muito significativa uma passagem no HGPE do dia 11 de setembro de 2010, filmada em Feira de Santana, na Bahia, no conjunto habitacional Nova Conceição, na sala da nova casa da família Silva que foi beneficiada pelo programa Minha Casa, Minha Vida. Na sala de estar, sentados no sofá, estão Dilma, Roberta Silva, seu esposo e os dois filhos pequenos do casal.

Dilma: O que significou para vocês quando chegaram aqui? Roberta: Eu não tenho palavras. Eu quero que as pessoas que não têm ainda, sintam esse privilégio, esse gosto. É gostoso assim... Hoje eu tenho uma casa. Hoje eu tenho essa oportunidade. Foi um presente, gente! Eu espero que a senhora continue. Não para não.

158 REVISTA DEBATES, Porto Alegre, v.5, n.1, p. 139-162, jan.-jun. 2011. 
Dilma: Pode ter certeza de que eu vou fazer casa por esse país. Para todo povo brasileiro que não tem casa. Porque não é a casa [cena do bebê brincando no chão e o garoto ligando a televisão]. É o que tem dentro da casa. São as pessoas, o significado pra você [cena do garoto abrindo o guarda-roupa em seu quarto] do que é ter uma casa. E eu acho que é isso que faz com que a gente tenha força para continuar brigando, pra continuar fazendo acontecer aquilo que a gente quer. Que é que o país cresça [cena externa: crianças brincando na quadra esportiva do Conjunto Habitacional Nova Conceição]. Mas que ele cresça para que a vida das pessoas melhore. Eu acho que é isso o que a gente quer [cena de Dilma carregando o bebê no colo ao lado da família]. Com o "Minha Casa, Minha Vida" estamos realizando o sonho da casa própria de milhares de famílias. Só aqui em Feira de Santana, na Bahia, são 28 conjuntos habitacionais. Seis deles já estão concluídos como esse, o conjunto Nova Conceição. Com o PAC 2 esse trabalho vai crescer, serão mais dois milhões de moradias em todo o Brasil.

\section{Considerações finais}

Pelo exposto, parece-nos claro que Dilma foi apresentada como candidata do lulismo. Dilma igual a Lula e o governo de Dilma igual ao governo de Lula. Aliás, a candidata foi apresentada como portadora de prestígio próprio, afinal, era a responsável, depois de Lula, pelo sucesso do governo. Nesse sentido, foi interessante perceber que apenas no primeiro programa Dilma diz: "por isso eu me orgulho tanto de ter participado de seu governo. E quero continuar e fazer avançar a sua obra". Nos demais programas, o seu/sua foram substituídos pelo nosso governo e nossas obras.

Em nossa visão, o epíteto Mãe do povo mostrou-se um recurso retórico - construído no interior da cultura - muito eficaz do ponto de vista político, uma estratégia sensível, capaz de apresentar o modelo de bom governo com forte apelo emocional. Mesmo impregnado de sentidos negativos, que circularam frequentemente na mídia, em editoriais, em colunas de jornalistas políticos ou nas análises de especialistas - paternalismo, populismo e uma visão arcaica da mulher - parece-nos que sua força no imaginário coletivo do brasileiro, sua eficácia como recurso de aproximação do eleitor, sua plasticidade em termos de composição de narrativas, imagens e de músicas emocionantes se revelaram mais potentes.

Enfim, considera-se que essa foi uma estratégia de formação da opinião pública que buscou dar conta de diversos desafios que se interpuseram na campanha: buscar identificação junto às mulheres, uma vez que Dilma precisava assegurar uma margem maior de votos válidos entre mulheres e consolidar votos femininos voláteis; deslocar o enfrentamento homem-mulher com o principal adversário, afinal homem não disputa com mãe; de continuidade, à imagem de Lula como Pai do povo; de dotar Dilma 
Rousseff de carisma: que o voto nela fosse um voto apaixonado, afinal, ela seria a primeira mulher presidente do Brasil.

Teresinha Maria de Carvalho Cruz Pires é Jornalista e Mestre em Sociologia (UFMG), Doutora em Comunicação e Cultura (UFRJ) e professora do Programa de Pós-Graduação em Comunicação Social "Interações Midiáticas" (PUC- MG). E-mail: pires@pucminas.br

\section{Referências:}

CASTELLÓN, Lena. Um filme de R\$16 milhões. M\&M Online, 23 dez. 2009. Marketing e Negócios. Disponível em: <http://grupomm.mmonline.com.br/noticias.mm?url=Um_filme_de_R_16_ milhoes $>$. Acesso em: 13 fev. 2011.

CASTRO, Maria Ceres Pimenta Spínola de; PIRES, Teresinha Maria de Carvalho Cruz. Opinião jornalística e eleições: o anti-lulismo e a apropriação do discurso populista. In: Congresso da Compolítica, 3., 2009, São Paulo. Anais do III Congresso da Associação Brasileira de Pesquisadores em Comunicação e Política. São Paulo: PUC SP, 2009. p. 1-21.

COSTA, Octávio; MARQUES, Hugo. É muito difícil Lula transferir afeto (Entrevista com Antônio Lavareda). Isto É, São Paulo, Edição 2079, s./p., 16 set 2009. Entrevista. Disponível em: <http://www.istoe.com.br/assuntos/entrevista/detalhe/18177_E+MUITO+DIF ICIL+LULA+TRANSFERIR+AFETO>. Acesso em: 27 set. 2009.

É UM FILME PARA O POVO, diz escritora. Folha de S. Paulo, São Paulo, 27 nov. 2009. Disponível em: <http://www1.folha.uol.com.br/fsp/brasil/fc2711200906.htm>. Acesso em: 30 nov. 2009.

FIGUEIREDO, et al. Estratégias de persuasão em eleições majoritárias: uma proposta metodológica para o estudo da propaganda eleitoral. In: FIGUEIREDO, Rubens (Org.). Marketing político e persuasão eleitoral. São Paulo: Fundação Konrad Adenauer, 2000. p. 147-203.

FOUCAULT, Michel. Microfísica do Poder. Organização e tradução de Roberto Machado. Rio de Janeiro: Graal, 1979.

GASPARI, Elio. A arma cinematográfica de Lula e Dilma. Folha de S. Paulo, São Paulo, s./p., 15 nov. 2009. Disponível em: 
<http://www1.folha.uol.com.br/fsp/brasil/fc1511200907.htm>. Acesso em: 30 nov. 2009.

KAMEL, Ali. Dicionário Lula: um presidente exposto por suas próprias palavras. Rio de Janeiro: Nova Fronteira, 2009.

LAVAREDA, Antonio. Emoções ocultas e estratégicas eleitorais. Rio de Janeiro: Objetiva, 2009.

MARANHÃO, Damaris Gomes. O cuidado como elo entre saúde e educação. Cadernos de Pesquisa, São Paulo, n. 111, p. 115-133, dez. 2000. Disponível em: <http://www.scielo.br/pdf/cp/n111/n111a06.pdf>. Acesso em: 03 fev. 2011.

MARTIN-BARBERO, Jesús. Dos meios às mediações. Comunicação, cultura e hegemonia. 4. ed. Rio de Janeiro: UFRJ, 2006.

MATOS, Marcley. "O sucesso de Lula é o meu sucesso" afirma Dilma. El País, Buenos Aires, s./p., 23 jun. 2010. Disponível em: <http://www.portal730.com.br/eleicoes-2010/12686-el-pais-qo-sucesso-delula-e-o-meu-sucessoq-afirma-dilma.html>. Acesso em: 21 ago. 2010.

MIRANDA, Débora. "Queria fazer um melodrama", diz diretor de filme sobre Lula. G1, Cinema/Festival de Brasília, 18 nov. 2009. Disponível em: <http://g1.globo.com/Notícias/Cinema/O,,MUL1383670-7086,00

QUERIA+FAZER+UM+MELODRAMA+DIZ+DIRETOR+DE+FILME+SOBRE+LULA .html>. Acesso em: 13 fev. 2011.

NOSSA, Leonencio. Lula dá nova versão para adiamento do início do PAC. $O$ Estado de São Paulo, São Paulo, s./p., 7 ago. 2009. Disponível em: <http://www.estadao.com.br/noticias/nacional,lula-da-nova-versao-paraadiamento-do-inicio-do-pac,415285,0.htm>. Acesso em: 30 nov. 2009.

OLTRAMARI, Alexandre. Lula não fará seu sucessor. Veja, São Paulo, Edição 2127, s./p., 26 ago. 2009. Disponível em: <http://veja.abril.com.br/acervodigital/home.aspx>. Acesso em: 27 set. 2009.

PARANÁ, Denise. Lula, O filho do Brasil. São Paulo: Editora Fundação Perseu Abramo, 2002.

. A história de Lula, o Filho do Brasil. Rio de Janeiro: Objetiva, 2009.

RICCI, Rudá. Lulismo. Da Era dos Movimentos Sociais à Ascensão da Nova Classe Média Brasileira. Brasília: Fundação Astrojildo Pereira, 2010. 
RODRIGUES, Fernando. Lula se beneficia na situação de vítima, diz publicitário João Santana. Folha de S. Paulo, São Paulo, s./p., 05 nov. 2006.

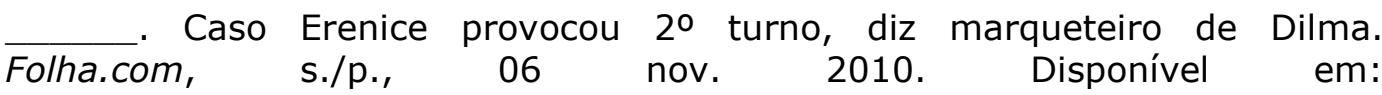
<http://www1.folha.uol.com.br/poder/826409-caso-erenice-provocou-2turno-diz-marqueteiro-de-dilma.shtml>. Acesso em: 10 nov. 2010.

SITE oficial do filme "Lula, o filho do Brasil"/Entrevistas. Disponível em: <http://www.lulaofilhodobrasil.com.br>. Acesso: 12 fev. de 2011.

SODRÉ, Muniz. As estratégias sensíveis: afeto, mídia e política. Rio de Janeiro: Vozes, 2006.

SOUZA FILHO, Danilo M. de. Filosofia, Linguagem e Comunicação. São Paulo: Cortez-CNPq, 1984.

THIOLLENT, Michel. Opinião pública e debates políticos: subsídios metodológicos. São Paulo: Polis, 1986.

VITTA, Oswaldo Luiz Colibri. Denise Paraná, biógrafa de Lula, explica a importância de dona Lindu. Rádio Brasil Atual. 2009. Disponível em: <http://www.redebrasilatual.com.br/radio/programas/jornal-brasilatual/denise_parana_p1.mp3/view>. Acesso em: 01 nov. 2010.

Texto recebido em 20/05/2011. Aprovado em 07/06/2011.

162 REVISTA DEBATES, Porto Alegre, v.5, n.1, p. 139-162, jan.-jun. 2011. 